\title{
The Empowering of Local Cityzen In Management and UtilizationCoastal Resources Makassar City
}

\author{
JaelanUsman and Adnan \\ Public Administration Department, Muhammadiyah University of Makassar \\ Jl. Sultan Alauddin No. 259 Makassar
}

\begin{abstract}
This study aimed to explain some of the key issues discussed, among others: (1) the process of empowerment of local people in the management and utilization of coastal resources; (2) the idea of shared government policy related institutions in the management and utilization of coastal resources, (3) the integration patterns of government and society in the management and utilization of coastal resources in Makassar City. The method used was a qualitative descriptive phenomenology approach to explain the empirical facts obtained related to empowerment of local people in the area of interest cape, cape independent, and cape spinach. Data collection techniques used was observation, in-depth interviews to informants who had been determined. Focused Group Discussion (FGD) in this study as well as a complementary alternative in data collection, particularly on the substance of research focus and linkages with key issues discussed in the first and second continuous year. The results of this study found that, management and utilization of coastal resources, especially in the area of Makassar flower cape, cape independent and spinach cape does not fully engage local communities in accordance with applicable conservation and sustainable development. These conditions affect the coastal sustainability and the environment, due to the degradation of coastal resource conditions indirectly caused by natural resource management in upstream effect on coastal estuaries. Particularly fishermen people who live in the coastal area of Tanjung Merdeka, TanjungBunga, Tanjung Bayam had two principal dimensions, namely the cultural dimension and structural. The cultural dimensions were efforts to change economic behavior, educational orientation, attitudes toward the development of technology, and habits.
\end{abstract}

Keywords: Empowerment, local people, coastal resources.

\section{INTRODUCTION}

Coastal areas and small islands were part of the natural resources that was given by Allah SWT, as the wealth controlled by the state and must be preserved and utilized as much as possible for the prosperity of the people both for the present generation and the generations to come. Therefore, the presence of Law No. 27 of 2007 on the Management of Coastal Areas and Small Islands are expected as a basis for management of coastal areas in the hope of the diversity of natural resources are high and very important contained in it can be developed for the benefit of the social, economic, cultural, environmental, and buffer state sovereignty to be managed in a sustainable and global perspective with the aspirations and participation of the community and nation that values based on national norms.

Similarly, Act 31 of 2004 on Fisheries stipulates that in order to implement national development based on the insights of the archipelago, the management of fish resources should be carried out as well as possible based on justice and equity in utilization. Equitable question is to realize the basic rights of people, namely: (1) the right to obtain decent work for humanity; (2) the right to obtain legal protection; (3) the right to acquire a sense of security; (4) the right to gain access to affordable necessities of life; and (5) the right to obtain justice. Without the fulfillment of these basic rights, would be difficult to expect the participation of people in development the marine sector.

Currently the coastal area of Makassar no longer a natural area that can preserve natural resources, habitats, and ecosystems that served to protect the surrounding area. The coastal area of Makassar was converted into residential areas, the center of economic and industrial activity. Logical consequences that arise include: environmental pollution (water, air, noise and soil), degradation of soil quality and the environment, conflict of interest and social problems, the emergence of environmental health problems, lack of clean water resources, and land use conflicts. Even in the Coastal region of Makassar exploitation of resources such as the use of fishery resources exceeds the total potency preservation, meaning that the level of fishing beyond the ability of fish development in the area.

In addition, the city of Makassar was a coastal region with rich natural resources of coral reefs and sea grass, but until now it has suffered severe damage. Special reef resources have been damaged almost half as a result of the activities of destructive fishing (poisoning and blasting) and coral and sand mining. Phenomenon a 
crucial place in the city of Makassar coastal Region was water pollution originating from waste disposal domestic industry stairs and marine transportation of oil spills, and the decreasing fish resources, so that the fishermen catch getting less. Based on this problem, the central issue that can be drawn was in addition to the policy (planning and decision making) overlapping, weak oversight, the institutional system was not functioning as well as the lack of involving local communities in management activities of coastal resources.

\section{REVIEW FOF LITERATURE}

Appearing of the concept of empowerment was as the antithesis of the top models of development that were less in favor of the majority of the people. This concept was built by logical framework as follows: (1) that the process of concentration of power centralization power awakenedproduction factors; (2) the concentration of power production factors will bear the working people and the business community outskirts; (3) the power will build the superstructure or the knowledge system, political system, the legal system and manipulative ideological system to strengthen its legitimacy; and (4) the implementation of the knowledge system, political system, the legal system and ideology systematically createdtwo groups society, namely the public power and poor people (SudirmanSaad, 2001). Therefore, what happens is the dichotomy, namely the powerful community and human-controlled. To free up the situation mastered and controlled, it must be released through an empowerment process for the weak (empowerment of the powerless).

The mindset was in line with the terminology of empowerment itself or known by the term empowerment that originated from the word power (power). Power in the sense of power comes from within, but can be reinforced with reinforcement elements are absorbed from the outside. It was concepts to cut out the main problem connect the power to the distribution of welfare. Underdevelopment and poverty that emerged in the development process due to the imbalance in the ownership or access to sources of power. A long historical process causes the power men, namely hiding the power in most societies, consequently people do not have adequate access to productive access was generally controlled by those who have power. Empowerment in the context of society was the ability of individuals who fused in the community and build community empowerment was concerned. People made up mostly of physical and mental health, well-educated and powerful, of course, have a high empowerment. Community empowerment was a basic element that enables a society to survive, and in terms of dynamic develop themselves and achieve progress. Empowerment of the community itself becomes the source of what is referred to as the political insight national security. This means that people had a high economic capacity, and then it was a part of the national economic resilience.

Based on the explanation within the framework of efforts to empower people think it is first necessary to begin with has created the atmosphere or climate that allows the potential for developing society. Here the starting point is the recognition that every human being, everyone had the potential to be developed. It means that there were not without power, because in that case will be extinct. Empower was an effort to build power itself, by encouraging, motivating and raise awareness of its potential and seeks to redevelop it. Furthermore, such efforts followed by strengthening potential or power possessed by the community itself. In this context, the necessary steps are more positive, apart from merely creating a climate and atmosphere conducive, also undertake concrete steps regarding the provision of inputs, opening access to a wide range of opportunities that will make people become more empowered (Haryanti 2004 ).

Empowerment was not only involved the strengthening of individual members of society, but also institutions. Instilling valued modern like culture of hard work, thrift, transparency, responsibility and others that are a key part of efforts to empower itself. Empowerment referred to in this study was an enabler-informal sector, especially the street vendors as part of the community which requires separate management of the government with regard to efforts to improve the quality of their resources, which in turn leads to an increase in operating revenues so that can contribute to the reception area of sector income levies. Preliminary studies relevant to this research, especially research conducted by Tajuddin (2011) with the title: Fishermen Makassar: Trust character, explaining that since the old people of South Sulawesi especially those living in coastal areas have traditional knowledge about the universe, including the marine environment, not only seen as the status of a vacuum or empty space that proceed naturally, but nature was experienced as an integral part of the Creator mystery. The people's concept of cultural knowledge that the universe was ruled by the God was natural elements like heaven, earth and sea surveillance and regulation submitted to the supernatural creatures and was known as a figure symbolizing good and evil.

Citizens who are elderly typically have no idea their minds about the kingdom centered on the ocean floor while its rulers is made up of descendants of the gods. The gods of the ocean rulers considered was related to god of the sky and the gods who rule on earth. After the influence of Islam, then gradually the myth of the underwater kingdom was shifted, and then came another myth that personifying the Prophet Hellerek. Until now, there has been obtained a clear explanation of the relationship between the Prophet Hellerek and all of Gods ruler of the kingdom under the sea. 


\section{RESEARCH METHODS}

The method used in this research was qualitative to describe as systematic, factual and accurate social phenomena that occur in the management and utilization of coastal resources in the area of interest headland, cape independent and spinach cape Makassar. Therefore, the research design used, among others: a case study and phenomenology related to the empowerment of local communities, especially the phenomena associated with efforts to accelerate development in the coastal area of Makassar. In addition, this study also used the technique collecting the data through observation, interviews, and Focused Group Discussion (FGD) were carried out with the involvement of stakeholders (government in this DKP / KKP Makassar, and resident's people around Barombong. Data analysis techniques was through Focused Group Discussion (FGD) as well as institutional and profile data collection monograph coastal areas. FGD activity carried out in two stages (levels), namely the city level and the district level. Applying FGD in this study was in the city of Makassar, particularly in Talamate district by taking the coastal area locations (cape flower, independent cape and cape spinach. Therefore, more focus on policy issues Makassar City Government empowerment of local communities in the management and utilization of coastal resources.

\section{City}

\section{RESULTS AND DISCUSSION}

\section{Empowerment of Local people in the Management and Use of Coastal Resources in Makassar}

In line with the implementation of regional autonomy, Makassar City Government has sought to take advantage of coastal resources in increasing revenue (PAD). Besides, the government also involved the community in the management and utilization of coastal resources, particularly in the area of Tanjung Bayam as expressed by one of the informants (Muh. Jufri DM) who was also the Secretary of the Institute for Community Empowerment (LPM) Village Barombong, in an interview on May 15, 2015 , that in order to boost economic growth and communities in coastal areas, especially in Tanjung Bayam has a very important role, because the management and utilization of coastal resources really pure initiative of local people. This was because the regional authority to manage the marine sector which includes coastal areas is still a new authority to municipalities, so that the management and utilization of coastal resources have not been fully implemented optimally.Management and utilization of coastal resources Makassar City Barombong region performed particularly by involving local communities mostly do not meet applicable requirements sustainably and continuously. These conditions affect the coastal and environmental sustainability. The cause of the degradation of coastal resource conditions indirectly was caused by natural resource management in upstream that affect the coastal estuaries. Reclamation policy that is not based on an analysis of environmental impacts in some coastal areas also affect the ecosystem in coastal areas.

The strategy developed coastal peoplethat can be done through two approaches, which were structural and non-structural. Structural approach was a macro approach that emphasizes the structuring of political systems and social structures. This approach prioritizes the role of the authorized agency or organization set up for marine coastal management. In this case the role of the community was very important but it will be less robust due to the structural aspects are usually more effective when done by those who have authority, at least in the early stages. On the other hand non-structural approach is a subjective approach. This approach prioritizes community development mentally to improve the ability of community members to participate in the management and utilization of coastal marine resources. Both of these approaches should be complementary and integrative implemented.

The main target of structural approach was well-organized structure and system of relationships between all the components and systems of life, both in coastal and marine areas as well as other supporting components, including components of social, economic and cultural. By structuring the structural aspects, the community is expected to get a greater opportunity to utilize natural resources in a sustainable manner. In addition system structure and social and economic relations are expected to create opportunities for people to participate in protecting the natural resources of the threats coming from both inside and outside. The move is expected to reduce or even eliminate the problems of social and economic principal that has been continuously putting the community (local) in a difficult position.

Subjective approach or are non-structural approach that puts human beings as subjects who have the discretion to take the initiative and do according to his will. Such an approach assumes that the local people with the knowledge, skills and awareness in order to enhance its role in the protection of natural resources around them. Therefore, one of the efforts to enhance the role of local communities in natural resource management, coastal and marine areas is to improve the knowledge, skills and awareness to do something to help conserve natural resources. Knowledge and skills are not necessarily directly related to the reduction efforts of natural 
resource degradation issue but also matters relating to economic activities; especially equip the community with alternative economic activities that do not harm the environment.

\section{Related Agencies Government Policies along the Coastal Resources Management and Utilization in Makassar City}

The concept of community development that emphasizes the empowerment it was formulated empowerment of coastal communities, especially fishermen who live in the area of Tanjung Merdeka, Tanjung Bunga, Tanjung Bayam Tamalate District of Makassar city, namely: (1) the fulfillment of basic human needs, including food, clothing, board, health and education; (2) the availability of production facilities and infrastructure locally that allows people to get a cheap price and good quality; (3) increasing the role of community institutions as a forum for collective action (collective action) to achieve individual goals; (4) creation of economic activities productive in the area and has characteristics based on local resources, a clear market, carried out in a sustainable resource capacity, as well as the impact on local communities, using appropriate technology derived from the process of research and study and (5) the creation of transport and communications links as the basis of economic relations between the coastal areas and between coastal and inland.

People empowerment coast of Makassar generally had two principal dimensions, namely the cultural dimension and structural. The cultural dimension included measures changes in economic behavior, educational orientation, attitudes toward the development of technology, and habits. While the structural dimensions included efforts to improve the social structures that allow for vertical mobility of fishermen. Structural reforms were generally in the form of strengthening the solidarity of fishermen to the next can gather in a group and an organization capable of fighting for their interests.

Makassar City Government has made efforts to empower fishermen structural and culturally, it was necessary to understand their unique social characteristics of fishermen who would demand a unique approach to empowerment as well. There are several principles of empowerment that are used for fishing communities, among others:

1) The principle of purpose, empowerment must be based on clear objectives, where fishing should be considered as a subject of development so the approach is helping fishermen to help himself to education and training.

2) The principle of knowledge and strengthening local value, that modern science now often considered powerful to overcome the various problems faced by fishermen, but they have their own knowledge system which is used as stock in empowerment, since knowledge is passed on for generations. Similarly, the local potential value as a basis for empowerment. Local value that can be an important social capital to be developed for the advancement of fishing communities.

3) The principle of sustainability, namely empowerment projects often do sometimes get stuck in the paradigm of project that requires the achievement of targets significantly in a short time. Thus, the principle of sustainability is often overlooked in empowerment projects during this time and it was due to the strength of the paradigm of empowerment projects in each activity. This happened because the nature of the project and not just momentary multiyear.

4) The principle of accuracy of target groups, namely the executor of empowerment often came to the village elite easier to communicate despite the fact that much of the problems of fishermen. While the poor fishermen who do not easily communicate even rarely visited. As a result, the information was obtained informant elite bias of fishermen, so it just touches the empowerment of fishermen elite that does not need to be empowered.

5) The principle of gender equality, one of the social characteristics of the fishermen is the strong role of women (wives of fishermen) in economic activity and decision-making. In this position, the empowerment included the wives of the fishermen, so that the empowerment of male bias is always invited to discuss and solve the problem quickly.

\section{Integration Patterns of Government and Community in Coastal Resources Management And Utilization in Makassar City}

ICZM known term Integrated Coastal Zone Management (ICZM) was first raised at the World Coastal Conference (World Conference of Coast) held in 1993 in the Netherlands. At the forum, is defined as the most concerning the matters of coastal management, both for the benefit of current and long-term interests, including as a result of loss of habitat, water quality degradation due to pollution, changes in the hydrological cycle, the reduction of coastal resources, sea level rise, as well as the impact of global climate change (Subandono, et al, 2009). Furthermore, underscored by Subandono that the concept PWPT provide a framework for planning and proper management in conquering various obstacles and problems in coastal areas, such as their institutional arrangements fragmented oriented bureaucracies on one sector, conflict of interest, lack of priority, rule of law, 
lack of knowledge of the position of the region and other social factors, as well as lack of information and resources.

Empowerment as a process of developing, independent, self-help, and strengthen, bargaining position lower layers of society against the suppressive forces in all areas and sectors of life. Empowerment of rural communities can also be understood or interpreted in the context of putting public standing position. The position of the people are not the object of the beneficiary (beneficiaries) are dependent on the provision of external parties such as the government, but rather in the position of the subject (agent or participant who acts) and act independently. In this case, act independently does not mean escape from the responsibility of the state. Provision of public services (health, education, housing, transport and so on) to the community was certainly a task (liabilities) of the country as a given. Independent community as participants mean open space and develop capacity-creation potential, control the environment and the resource itself, solve the problem independently, and also determine the political process in the realm of the state.

Poverty was a lagging indicator of coastal communities was caused by at least three main things: (1) structural poverty, (2) super-structural poverty, and (3) cultural poverty. Structural poverty is poverty due to the influence of external factors or variables beyond the individual. These variables are the socio-economic structure of society, the availability of incentives or disincentives development, the availability of development facilities, availability of technology, and the availability of resources, especially natural resource development. The relationship between these variables and poverty are generally reversed. This means that the higher the intensity, volume and quality of these variables, the poverty wanes. Especially for the socio-economic variables, their relationship to poverty is more difficult to determine. It was obvious that the socio-economic condition of society was happening around or in the scope of the fishermen determined poverty and well-being.

Super-structural poverty is poverty caused some macro policy variables that are not so strong in favor of the development of fishing. Variables such superstructures including their fiscal policy, monetary policy, the availability of the laws and regulations, government policies are implemented in development projects and programs. Super-structural poverty is very difficult to overcome if they were not accompanied by a genuine desire and willingness of the government to address them. The difficulties also caused by competition between sectors, between regions, and between institutions that make so that there was an imbalance and the development gap. Super-structural poverty could only be overcome if the government, both central and local levels, has a special commitment in the form of biased actions for the benefit of the poor.

Cultural poverty was poverty caused by the variables inherent, inherent, and be certain lifestyle. As a result, the individual concerned is difficult to get out of poverty, because it is not recognized or not known by the individual concerned. Variables cultural causes of poverty were education, knowledge, customs, culture, beliefs, loyalty to certain views, as well as adherence to a model. Structural poverty was difficult to overcome. Generally the influence of role models (patron) even though informal, informal, and or native (indigenous) was critical to the success of the efforts of this cultural poverty alleviation. Research in some Asian countries where people made up of several religious groups also showed that religion and the values of public trust had a very significant influence on the socio-economic status and family.

\section{CONCLUSION}

Based on the research and discussion above, it can be concluded as follows: (1) Empowerment of local people in the management and utilization of coastal resources in Makassar based on facts obtained showed that, management and utilization of coastal resources in the region Barombong done with community involvement local not meet applicable requirements sustainably and continuously. These conditions affected the coastal and environmental sustainability. The cause of the degradation of coastal resource conditions indirectly was caused by natural resource management in upstream that affect the coastal estuaries. Reclamation policy that is not based on an analysis of environmental impacts in some coastal areas also affect the ecosystem in the coastal area of Makassar; (2) The government policy and related institutions in the management and utilization of coastal resources Makassar City according to the results of research and discussion it was discovered that the fishing communities especially those living in the coastal area of Tanjung Merdeka, Tanjung Bunga, Tanjung Bayam Village Barombong Tamalate District had two key dimensions, namely the cultural dimension and structural. The cultural dimension was to include measures changes in economic, educational orientation, attitudes toward technology development, as well as habits. Structural dimensions are efforts to improve social structures enabling the vertical mobility of fishermen. Such improvement was generally in the form of strengthening the solidarity of fishermen to the next can gather in a group and an organization capable of fighting for their interests, and (3) Integration of the community and the government in the management and utilization of coastal resources of Makassar question is, management of integrated coastal known term Integrated Coastal Zone Management (ICZM) was first raised at the World Coastal Conference (World Conference of Coast) held in 1993 in the Netherlands. At the forum, is defined as the most concerning the matters of coastal management, both for the benefit of current and long-term interests, including as a result of loss of habitat, water quality 
degradation due to pollution, changes in the hydrological cycle, the reduction of coastal resources, sea level rise, as well as the impact of global climate change.

\section{BIBLIOGRAPHY}

[1] Agusta, I. 2000. Asumsi-Asumsi Program Pemberdayaan Masyarakat Pedesaan Indonesia, Alam Mimbar Sosek Th. 12 No. 3 April 2000.

[2] Arief, Andi Adrie, 2008. Partisipasi Masyarakat Nelayan di Kabupaten Takalar (Studi Kasus Desa Tamasaju, Kecamatan Galesong Utara).Jurnal Hutan dan Masyarakat Vol. III No. 1 Mei 2008.

[3] Arief.Muhsin.M. 2016. The Developtment of Creative Writing Model on Short Story Based Siri'Na Pacce at the XI Class Senior High Schools in Makassar. Journal of Educational and Social Research, $6(1), 52$.

[4] Adrianto. L. 2005. AnalisisSosialEkonomiDalamStrategiKonservasiSumberDayaPesisirDanKelautan: PendekatanCoastalLivihoodAnalysis.Makalah. PKSPL. Bogor.

[5] Aidah Husain, 2006. Studi Optimalisasi Zonasi Taman Nasional Laut Takabonerate. Makalah Seminar Kelautan, Unhas, Makassar.

[6] Bailey, Stephen, J. 1999. Local Government Economics: Principles and Practice, Mac Millan Press Ltd., Great Britain.

[7] Bengen, D.G. 2001.Pengelolaan Sumber daya Wilayah Pesisir Secara Terpadu, Berkelanjutan dan Berbasis Masyarakat. Bogor: Makalah pada Sosialisasi Pengelolaan Sumber daya Berbasis Masyarakat.

[8] _ 2002. Sinopsis Ekosistem dan Sumberdaya Alam Pesisir dan Laut Serta Prinsip Pengelolaannya. Bogor: PKSPL-IPB.

[9] Besley, T. \&Coate, S. 2003. Central Versus Local Provision of Public Goods: APolitical Economy Analysis.Journal of Public Economics 87, hal. 2611-2637.

[10] Dahuri, Rokhmin. 2000. PermasalahanPengelolaanLingkunganKawasanPesisir. Journal Ekologidan Pembangunan, No. 4Agustus 2000.PPSDAL-LPU niversitasPadjadjaran.

[11] 2004. PengelolaanEkosistem Wilayah Pesisir dan Lautan.Yogyakarta: Gadjahmada University Press.

[12] Emmy Hafid, 2006.PotretKelautan di Masa Kin.Artikel ilmiahMajalah Tanah Air WalhiNomor 3 Tahun XXI, Jakarta.

[13] Hardjasumantri, Koesnadi. 2004. Hukum Tata Lingkungan. Yogyakarta: GadjahMada University Press.

[14] Heryanti, 2004.Peran Serta masyarakatdalamPengelolaan Wilayah Pesisir.TesisPascasarjanaUnhas, Makassar

[15] IrwandiIdris, 2002. Ko-Manajemen Perikanan Pantai Masyarakat Adat dan Pemerintahan di Indonesia.MakalahpadaKonvensiNasional Pembangunan Benua Maritim Indonesia Dalam Rangka Mengaktualisasikan Wawasan Nusantara. Jakarta: Dewan Pertahanan Nasional.

[16] Julianti, 2005.AspekHukumPenggunaanBomdanBiusIkan di Taman NasionalTakabonerate.JurnalIlmiahHukumClavia, Volume II, Universitas 45 Makassar.

[17] Latama, G., et al. 2008. Pengelolaan Wilayah Pesisir Berbasis Masyarakat diIndonesia: http://walhijabar.wordpress.com/2008/01/10/pengelolaan-wilayah-pesisir-berbasis-masyarakat-diindonesia/, diakses 21 Oktober 2015.

[18] Kusumastanto, T. dan Muhammad Ramli, 2000.KebijakanSetengahHatisertaKemakmuranSemu di PesisirdanLautan.Warta PesisirdanLautan. Bogor: PKSPL-IPB.

[19] Maknun, Tajuddin, 2011. Nelayan Makassar: KepercayaanKarakter. (Makassar: Penerbit Identitas Unhas).

[20] Mochtar Kusuma Atmadja, 2003. PerlindungandanPencemaranLingkunganLaut di Lihat dari sudut Hukum Internasional, Regional dan Nasional. SinarGrafika, Bandung

[21] Monoarva, 1999.KarakterStudidanBudayadalamPengembanganPerikananBerskala Kecil.UI Press, Jakarta.

[22] Muhsin, Arief.M. 2016. The Effectiveness of Positive Feedback in Teaching Speaking Skill. Lingua Cultura, 10(1), 25-30.

[23] Nasruddin, 2011.Patorani: Sang PemburulkanTerbangdalamKearifanLokal di Tengah Modernisasi. (Jakarta: KementrianKebudayaandanPariwisataRepublik Indonesia).

[24] Nikijuluw Victor, 2001. Populasi dan Sosial Ekonomi Masyarakat Pesisir serta Strategi Pemberdayaan Mereka Dalam Konteks Pengelolaan Sumberdaya Pesisir Secara Terpadu. Bogor: IPB.

[25] Pelras, Christian, 2006. ManusiaBugis. Jakarta: Nalarkerjasamadengan Forum Jakarta Paris.

[26] Rudyanto, Arifin. 2004. Kerangka Kerjasama dalam Pengelolaan Sumberdaya Pesisir dan Laut. Jakarta: buppenas.

[27] SudirmanSaad, 2001. Desemntralisasi Pengelolaan Wilayah Laut. Prosiding Lokakarya Regional Pulau Sulawesi. Makassar 12-14 Maret 2001. 
[28] Sugandhy, Acadan Rustam, H. 2007. .Prinsip Dasar Kebijakan Pembangunan Berkelanjutan Berwawasan Lingkungan. Jakarta, Penerbit Bumi Aksara.

[29] Sugiarto, 2005.Kependudukan dan Lingkungan Hidup (Tantangan Pembangunan di Indonesia Timur. Pustaka Sinar Harapan, Jakarta.

[30] Suyanto, Igit. 2005. Studi Implementasi Program Pemberdayaan Masyarakat Pesisir (PEMP). Semarang: Tim DKP Kota Semarang

[31] Undang-Undang No. 32 dan 33 Tahun 2004, tentang "Pemerintahan Daerah", dan Perimbangan Keuangan Antara Pemerintah Pusat dan Pemerintah Daerah. Aneka Ilmu, Jakarta.

[32] Undang-UndangRepublikIndonesiaNomor 27 Tahun 2007 Tentang Pengelolaan Kawasan Pesisir dan Pulau-Pulau Kecil.

[33] Widodo, Joko. 2001. Good Governance Telaah dari Dimensi Akuntabilitas dan Kontrol Birokrasi pada Era Desentralisasi dan Otonomi Daerah, Surabaya: Insan Cendekia. 